\title{
SEROLOGICAL STUDIES ON BRUCELLA IN DAKHALIA AND DAMIETA GOVERNORATES
}

\author{
G. Younis and Amal Abdel-Satar Ibrahim \\ Dept. Bacteriol. Mycol. Immunol., Fac.Vel.Med., Mansoura University
}

\begin{abstract}
A total of 665 blood samples were first screened for Brucella antibadies by using Rose Bengal Plate test. The positive reactors were further confirmed by tube agglutination test. Results of the examined dairy cattle sera revealed that the incidence of brucellosis was 29.17\%. A total of 320 milk samples were also screened and the results revealed that 102 (31.9\%) were positive after tested by MRT. In corresponding, milk whey samples were tested by whey serolagical tests (WRBPT and WTAT). WRBPT recorded 52 posittue samples (16.3\%) and WTAT recorded 42 (13.1\%). MRT was taken as a reference standard test for evaluating WRBPT and WTAT. The sensitivity was (50.9\%) and (41.1\%) for WRBPT and WTAT respectively. while the specificity was (100\%) for each and the agreement was $84.4 \%$ and $81.3 \%$ respectively. On the other hand, the results showed the disagreement between serum and whey serological tests and the relative agreement between MRT and serum agglutination tests. Moreover, examination of 100 marketing milk samples was found to be negative to MRT.
\end{abstract}

Key words: Rose Bengal, sensitivity, specificity. Brucella, milk whey. Inilk ring test.

\section{INTRODUCTION}

Brucella, a genus of gram negallvc bacteria, is a causative agent of bruccllosis, a worldwide zoonotlc disease (Corbel and Morgan, 1984). Brucellosis has been studied in domesticated mammals, such as cattle, sheep and pigs, and is known to cause reproductive disorders or abortlons in infectcd animals. Brucella organisms can be transmitted from infected animals to man by ingestion of unpasterized inllk and milk products, by contact with infected anlmals or elther diseharges or by inhalation of aerosols contalning Brucella organlsms (Refal, 2003). Also, transmission via blood transfusion, bone mantow transplantation, sexual Intercourse and neonatal
Infectlon had been reported (Palanduz et al., 2000). Therefore, un-pasterized milk. cream. butter, unfermented cheese and other products made from untreated milk eonstitute a serlous health hazard in area where Brucella infection is wide spread in dalry animals (Munoz et al., 1993). The exeretion may stop In advanced lactation perlod but starts again in the subsequent lactation. The organism leads to serlous economic losses for anlmal Industry due to abortion, losses of calves, reduction In milk yield by $7-20 \%$, some breeding troubles in infected animals and veterinary costs of dlagnosis and control measures (Sollman, 1998). Moreover, the organlsm is responslble for the disease in man ealled undulant fever 
whIch is characterzed by intermittent lever, headaehe, fatlgue. jolnt and bone paln. psychotic disturbances and other symptoms (Refal, 2003; and Pappas et al., 2005). Dlagnosis of brucellosis is the comer stone of proper eradication of the disease. Isolation of the causative agent is still the land mark for diagnosis of brueellosis (Alton et a1., 1988) but beeause of the eost. difficulty of performance and lack of sensitivity of most culture procedures, serological dlagnosls is the main tool used for detection of Brueella infeetion in animals. Although a wide range of serodiagnostic tests are avallable, there is no single test is capable to identify all infected antmals with brucellosis (Davies, 1971; and Salem et al. 1987). Presence of antibady to Brucella infection has been reported to be deteetablc later In milk than in serum therefore it is reasonable to expect that milk antibody levels refleet the serological picture of the anlmals (Alton et al., 1988). Testing of mllk has some advantages over testing of serum samples providing that a single test ean be applied to large numbers of eattle, sample condttion is not critical and sampling is less expensive (Nielsen et al., 1996). It is easier for using milk and milk whey for dlagnosis of brucellosis as injuring animals for collecting blood samples Is difflcult (Farag, 1998).

\section{MATERIAL AND METHODS}

This research was direeted to detect the presence of brucellosis in dalry animals in Dakahila and Damieta governorates using serologieal tests.

\section{Sampies:}

A total of 665 serum samples from (500 from diflerent cattle farms, 125 sporadic cases distributed In Dakahlla and Damieta gov- emorates and 40 from Mansoura abattolr). Also, another 320 milk and serum samples from the same eows were collected from NewDamleta farm for eompanson between their results. Finally, 100 market milk samples were tested for presence of Brueella antlbodles.

\section{Preparatlon of whey:}

It was done according to Morgan et al. (1978). $10 \mathrm{ml}$ milk samples were centriluged at $3000 \mathrm{rpm}$ for $10 \mathrm{minutes}$ to separate the fat layer, the fat layer was removed and two drops of eommerelal rennet were added to approxdmately $10 \mathrm{ml}$ of skimmed milk. The tube was ineubated at $37^{\circ} \mathrm{C}$ for 2 hours. and then centrifuged at $2000 \mathrm{pm}$ for 10 minutes for preeipitation of easeln. The obtalned clear whey was elther stored under deep freezing till testing by various serological tcsts or $1 \mathrm{~m}$ mediately used.

\section{Antigens:}

Rose Bengal plate test antigen, tube agglutination test antigen and milk ring test antigen (Haematoxyllne blue antigen) were purehased from the Veterinary Sera and Vaccines Instltute, Abbissia, Cairo, Egypt.

4. Serologleal examination of milk, whey and serum samples:

1) Milk Ring test (MRT) (Alton et al., 1988):

The bottles containing individual milk samples werc thoroughly mixed. From each sample, $1 \mathrm{ml}$ of milk was placed in a separate Wassermann tube. One drop of haematoxyline stained milk ing test antigen ( 30 micron) was added to each tube. The contents were mixed gently by inverting the tube several times (avolding loam formation). Then the tubes were Incubated at $37^{\circ} \mathrm{C}$ for one hour. 


\section{Interpretation of the results:}

Four, three and two are considered as positive while one score Is Inconclusive.

2) Rose Bengal Plate Test (Morgan el al., 1978):

Samples and the Rose Bengal Plate Test antgen were brought to room temperature before testing. One drop (30 micron) of serum under test was dellvered on dry white enamel plate using a mlcroplpette, and then one drop (30 mieron) of Rose Bengal anugen was dispensed adjacent to the sample. By using a toothpick, the antigen and the serum were thoroughly mixed in a circular movement. The plate was rocked by hand for 4 minulcs. The test was read immediately after this roeking period of the enamel (4 minutes) at room temperature. Posituve and negatuve controls were Ineorporated.

\section{Interpretation of the results:}

++++: Agglutination within one minute's coarse granules.

+++ : Agglutination within two minutes with medium granules

++ : Agglutination within three minutes wilh fine granuks.

$+\quad$ : Agglutination within four minutes with very fine granules.

- : No agglutination occurs within four minutes.

3) Tube agglutination test (TAT, European method) (Alton et al., 1975):

It was done In clear glass Wassermann lubes and in view of the occasional occurrence of prozone phenomena at least five tubes were used per sample. The tubes were arranged in rows in a sultable rack. Using $1 \mathrm{ml}$ pipette, $0.8 \mathrm{mi}$ of phenol sallne $0.5 \%$ (contalning normal saline $0.85 \%$ ) were added to the nrst tube and $0.5 \mathrm{ml}$ In each succeeding tubes. To the Arst tube, $0.2 \mathrm{ml}$ of the sample under test were added and mixed thoroughly within phenol saline. then $0.5 \mathrm{ml}$ of the mixture were carned over to the seeond tube. From whleh after thorough mlxing, $0.5 \mathrm{ml}$ of the mixture was transferred to the third tube. The process was contnued unt the last tube. from which after mlxing. $0.5 \mathrm{ml}$ was discarded. This process of doubling dilutions resulted In $0.5 \mathrm{ml}$ dilutions $1: 5,1: 10,1: 20$ and $1: 40$ and so on in each tube. To each tube. $0.5 \mathrm{ml}$ of antigen dilution $1: 5$ In phenol sallne $0.5 \%$ was added. The content was mixed thoroughly resulting in final sample dilutions of $1: 10$. $1: 20$ and $1: 40$ and so on. The tubes were incubated at $37^{\circ} \mathrm{C}$ for approximately 10 hours \pm one hour before reading the results. Parallel with the test. positive and negativc eontrols were Ineluded. Samples with highest titres were tested with more dilutlons to determine thelr end tutres.

\section{Reading:}

The tubes were examined without shaking agalnst a black background with the light coming from above and behind the tubes as follows:

4+: Complete agglutination and sedimentaton with clear supernatant.

3+: Nearly complete agglutination with $50 \%$ clearance.

2t: Marked agglutination with $50 \%$ clearance.

1+: Slight agglutination with $25 \%$ clearanee.

-ve: No agglutination.

The highest dilution showing $50 \%$ or more clearanee was taken as the end titre for the sample. 
Interpretation of the results:

A titre corresponding to antibodles levels of $20 \mathrm{IU} / \mathrm{ml}(++1: 10)$ or higher was used as an Indicative of infection.

Biostatical analysis (Crawford and Hidalogo, 1977).

A diagnostic test should have a high validlty. which means that the percentages of false positive and falsc negative should be limited. Validity expressed by the sensitivity and specinclty. The sensitivity of a test can be denned as the conditional probabillty that is test will Identify all individuals with brucellosis in glvcn population. while the specificlty can be defined as the conditional probability that the test will identify all non diseased Individuals.

The sensitivity and specificlty of a test:

They were calculated according to (Crawford and Hidalogo, 1977) as follows:

Relatlve sensitlvity $=$ True positlve $\times 100$

True posltivc + false negatve

Relative speciflcity $=$ True negatlve $\mathrm{X} 100$

True negative + false negatlve

Agreemcnt $=$ bolh lests postlive + both tests

$\frac{\text { negatlve } \times 100}{\text { Total cases examined } \times 100}$

\section{RESULTS AND DISCUSSION}

Brucellosis is still considered a serlous diseasc affecting both man and animals (Sollman. 1998). An important factor responsible for the spreading of brucellosis in Egypt is the uncontrolled importation of cattle from some countries where brucellosis is still prevalent (Shalaby, 1986) He also added that the lack of proper programmed of quarantlne measure for imported animals to ensure their free from the disease before being introduced Into our country. Dlagnosis of bricellosis based on
Isolation of the organism from the infected anImals is time consuming task due to the fact that these lastldious organisms grow slowly on primary Isolation (Meyer, 1981). Moreover, it is not possible to Isolate Brucella every ume from known Infected Individual (Ray. 1979). therefore, assessment of antbody response employing serological tests plays a major role in the routine diagnosis of brucellosis and supported appropriate by bacteriologlcal examination (Alton et al., 1988).

As shown in table (1), out of 665 serum samples collected from cows, 194 samples showed positive results after thelr screening by using Rose Bengal plate test with an incidence of $(29.17 \%) .7(1.1 \%), 45(6.8 \%), 76$ (11.4\%) and 66 (9.9\%) of samples showed t1tres of $1 / 20,1 / 40,1 / 80$ and 1/160 respectively as demonstrated in table (2). Incldence of Brucclla antlbodies in cow's milk samples based on results of Milk Ring Test (MRT) as recorded In table (3) where out of 320 tested samples, 102 gave positlve with MRT (31.87\%). Nearly similar result was obtalned by Abdel- All (2001) who recorded an incidence of (31.66\%), but, lowest result (0.62\%) was recorded by Kadry (1996). In reverse. highest result (76.47\%) was recorded by All et al. (1993).

Regarding whey, 52 samples (16.25\%) were positlve by RBPT. The obtained result is nearly similar to selim (1987) who recorded (16.1\%) positive result. Negative resuits wcre recorded by Onst (2004). Meanwhlle, high results were stated by Abd El Rahman (1991). Concerning whey TAT, 42 positive samples were recorded with an incidence of (13.12\%). 2 (0.63\%), 4 (1.25\%), 24 (7.50\%) and 12 (3.75\%) of samples showed titres of 20.40.80 and 160 respeetvely as shown in table (4). In 
contrary, a relatively highest percentage (49\%) was reported by Hamdy (1997) and negatuve result was oblained by Onst (2004).

Comparing the results whlch obtalned by wTAT and those of wRBPT, it was evident that wTAT was relatively less sensitue as it gave $13.1 \%$ positive reaetors whlle it was $16.25 \%$ for wRBPT. The lower sensituvty of wTAT may be attributed to the certaln limitation of this test espeelally in early Incubation and in the later chronic stage of disease (Morgan, 1967; Nicolettl, 1969; and Davies, 1971\}. Furthermore, this agglutination test was falled to detect IgGI antibodies, since. these anlibodies can not agglutinate antugen at $\mathrm{pH}$ value near neutrality and when in excess. These antihodles are llable to block the agglutination activty of other isotypes resuiting in false negalive reaction (Ahmed et al., 2002).

From data presented In table (5). It was stated that low sensitivity of wRBPT and WTAT $(50.9 \%$ and $41.1 \%)$ in comparison to MRT could be attributed to cretin factors such as removal of solid part in milk with rennin, the change in $\mathrm{pH}$, change in moleeular weight of some immunogiobulins and the presence of majority of Immunoglobulins in comparison to raw milk. Therelore the whcy contains lewer amounts of Immunoglobulins in comparison to raw milk with cream (Sutra et al. 1986; Hamdy, 1897; and Abd-Alla et al., 2000). In addition, the whey tcsts are less scnsitlve, but less influenced by non-specticic faclurs than MRT and produce more conflmatory results (Cruickshank and Duguid 1968, Morgan et al. 1978; El-Gibaly and Rashad, 1890; and Handy 1987).

MRT may glve false positive reaction when the samples were taken near the end of lactauon cycle from mastluc milk quarters with hormonal disorders shortly aiter parturition and when the colostrums included in the samples (Corbel and Morgan, 1984; and Macmallian, 1990).

Also, non specinc reaction to MRl was rcported In case of increase in proteln levels In milk to about 3-15 times than the normal level (Hajdu, 1984). Moreover, non specIflc reaction of MRT was reported due to presence of cross- reacting bacterla (Stuart and Corbel, 1982; and Corbel and Morgan, 1984).

By testing the serum samples with RBPT and 'ГAT, 91 serum samples produced posltive results for each with an incidence of $(28.43 \%)$. These results show disagreement between blond serum and whey scrological tests thrat were also reported by El-Gibaly and Rashad (1990) and Hamdy (1997). It could be attributed to the delatining process bcfore the performance of the whey tests. since: most of the Immunoglobulins are present on the surface of the fat globules. Moreover, removal of solid parts by rennin, change in $\mathrm{pH}$ and change in the molecular weight of immunoglobulin could be other additional ractors that lead to low sensitivity of whey agglutination test (Hamdy, 1897).

Agreemcnt betwecn MRT and blood serum serological tests revealed that the MRT has highest ratlo of agreement with RBPT and TAT. On the other hand, MRT failed to identily many samples whlch gave positivc reactlon with blood serum serological tests. These may be attrlbuted to the stage or infection. where udder antibodies appear later than serum antibodies $(40 \%$ In 4 week. $60 \%$ in 8 week. $70 \%$ in 13 week, $100 \%$ in 20 week) after the appearance of serum antibodies or to the Irregularity in the filtration of agglutinins from 
Meyer, M. E. (1881): The genus Brucella in the prokaryotes. Star, M.P.: Stolp. H.G.; Balows, T.A. and Schlegel, H.G. 10631074. Sprlng. Berlin, Heldelberg, New: Yoik.

Morgan, B. W. J. (1967) : The serological dlagnosis of bnicellosis. Vet. Res 80 (21):612621.

Morgan, W. J. B.; Mackinon, D. J.; Gill, K. P.: Gower, S. G. M. and Norrs, P. I. W. (1978) : Diagnosis standard laboratory techniques. MInistry of Agriculture, Fisheris and Food. 2nd Ed. Central Veterinary Laburatory. New Haw, Weybridge, Surrey. England.

Munoz, C. J. L.; Benapldes, A. S.; Casared, F. G.; Guerrero, B. M. $A$ and Castellanos. V. T. (1993) : Study of brucellosis outhreak and diagnostic evalutlon of laboratory test. Revista medica $\mathrm{Dcl}$ Instituto Mexicano Del Segurasocial, 31(4): 273-277.

Nicolecti, P. (1969): Further eviluatlon of sernlogical test procedures used to dlagnosis hrucellosis. Am.J.Vel.Rcs. (30):1811-1816.

Nielsen, K.; Smitrh, P.: Gall, D.; Perez, B.; Cosma, C.; Mueller, P.; Trattler, J.; Cote, G.; Boag, L. and Bosse, J. (1986) : Development and validation of an indireet enzyme linked immunosorbent assay for dctection of antibody to $B$. abortus in milk. V'ct. Miciobiol., 52 : 1-2, 165-173.

Ons1, A S. (2004) : Serolngical studies on milk for diagnosis of Brucclla infection in Assint governorate M. V. Sc. thesis Fac. Vet. Med., Asslut Univ., Egypt.

Palanduz, A: Palanduz, S.; Guler, K. and Guler, N. (2000) : Brucellosis in a mother and her young infant: Probable transmission by breast inllk. Int. J. In-
fect.Dis. , 4(1):55-56.

Pappas, G.; Nikolaos, M. S.; Akritldis, M. D.; Nule Boalkorsti, $M, D$. and Epamelndas, M. D. (2005) : Brueellosls. The New England Journal of Medxelne. 352(22): 2325-2336.

Pat, K. V. and Panlgraphl, B. (1965) : Cornparatue study on the Aborkus Bang Ring test In cows and buffaloes. Indian Vet.J.. 42:748.750.

Ray, W. C. (1979) : Brucellosis CRC handbook series in zoonosis by stcel, J.H., CRC Press. INC., Boca Raton. Florida.

Refal, M. (2003) : Brucellosis in antmal and man In Ésypt. Egypt.J.Vet.Scl., 37: 1-31.

Salem, A A. E1-Glbaly, 5. M.; Hassan, M. S. and Hosien, H. 1. (1987) : Sens!tivity of some dlagnostle procedures for brucellosis in eattle. Assiut Vet.Mcd.J., 18(36): 159 162.

Sellm, O. M. (1987) : Seroepideminlogleal studles on brucellosis in dairy cattle and man. M.V.Sc thesis. Fac.Vet.Med., Cairo Univ., F.gypt

Shalaby, M. N. (1986) : A survey on bruccllosis as a cause of reproductive disorders in farm animals In Egypt. M. V. Sc. thesis. Fac. Vet. Med., Calro Unlv.

Soliman, S. A. M. (1998) : Studics on bruce]losis in farm anlmals with reference to publle health Importanee In Su'z Canal district. Ph.D. thesis, Fac.Vet.Med., Sucz Canal Univ.

Stuart, F. A and Corbel, M. J. (1982) : Idenuflcation of a serological cross reaction between B. abortus and E.coli:O157. Vet. Rec., 110-202.

Sutra, L.: Cafnn, J. P. and Dubray, G. (1986) : Role of milk immunoglobulins in the Brucella Milk Ring Test. Vet. Microblol., $12(4): 359-366$. 


\section{الملحص العربى}

دراسات سيرولوجية على البروسيلا فى محافظتى الدقهلية ردمياط

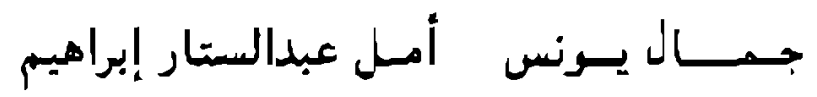

تسم البكتبريا وا'نطريات رالثاعن - كلب الطب البطرى - جاست المنصررة

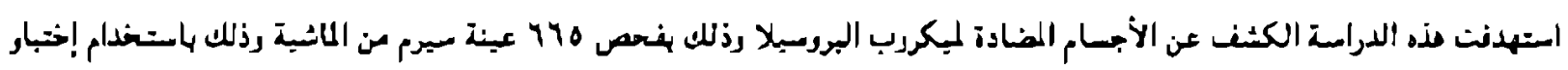

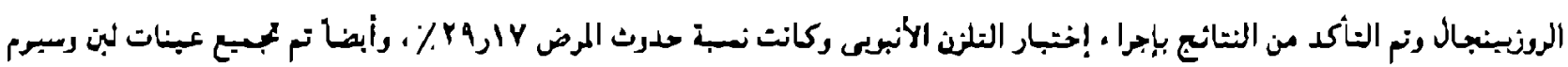

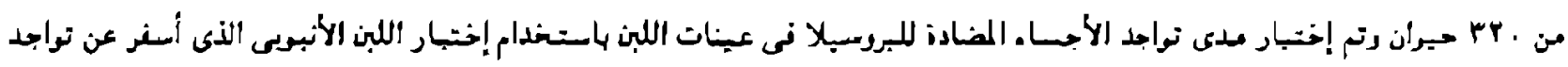

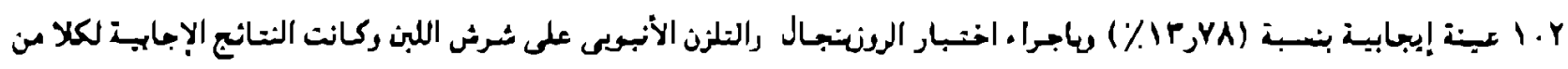

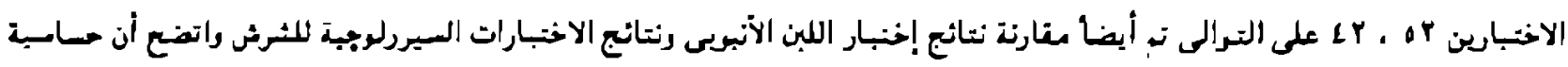

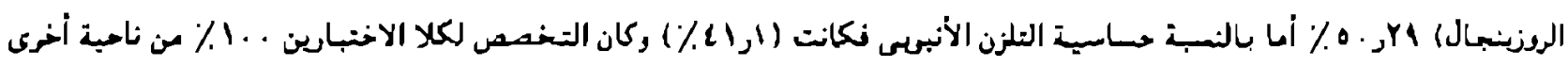

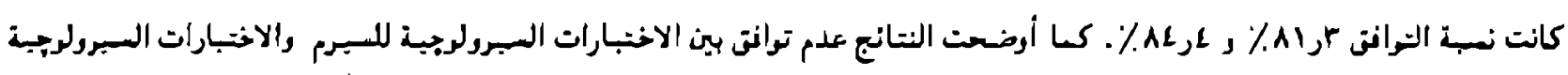

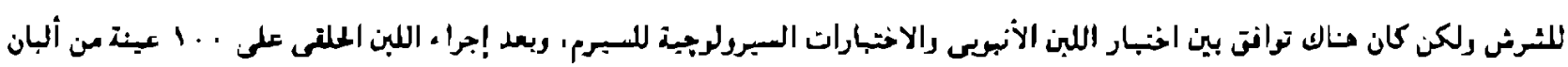
التسريت كانث نـبية ثواجد الأجسام الضادة للبروسيلا سعدومة. 